(RESEARCH ARTICLE)

\title{
The investigation of toxic, genotoxic and cytotoxic effects of various nanoparticles in Allium cepa and Caenorhabditis elegans test systems
}

\author{
Atacı Gamze and Türkoğlu Şifa* \\ Cumhuriyet University, Faculty of Science, Deparment of Biology, Sivas Turkey.
}

Publication history: Received on 16 December 2019; revised on 07 January 2020; accepted on 09 January 2020

Article DOI: https://doi.org/10.30574/wjarr.2020.5.1.0108

\begin{abstract}
In this study, toxic, genotoxic and cytotoxic effects of titanium dioxide (TiO2), silicon oxide (SiO2), zinc oxide (ZnO), copper oxide ( $\mathrm{CuO})$ and aluminium oxide (Al203) nanoparticles on Allium cepa (A. cepa) and Caenorhabditis elegans $(C$. elegans) model organisms were investigated. 25, 50, and $100 \mu \mathrm{g} / \mathrm{ml}$ doses of these substances were applied to $A$. cepa roots for 12 and 24 hours. At the end of the study, it was determined that mitotic index decreased and chromosomal abnormalities occurred. As a result of the application doses of these substances to C. elegans nematode, survival time decreased, egg production decreased and physical growth decreased.
\end{abstract}

Keywords: Nanoparticle; Allium cepa; Caenorhabditis elegans; Genotoxic effect; Toxicology

\section{Introduction}

Although nanoscience is in its early stage, its effects are seen both in our daily life and in nature. Nanoscience and nanotechnology is a multidisciplinary situation, creating a broad coverage area that involves many researches that require cooperation. For many different purposes, nanoparticles (NPs), which have a wide range of uses, are now taking place in every aspect of our lives. NPs are seen in every area from medicine to textile, from cosmetics to high technology. Due to this science, one million movies can be made on DVDs; nanorobots that find and heal the diseased tissue within the human body and perform the surgery can be used; the capacity of the human brain can be strengthened with additional nano memory; 50 times lighter than per unit weight and more durable material can be produced. In addition, new rocket and aircraft designs will be possible to emerge in space research and aviation. All these developments are scientific and technological evolution that can reshape the world.

However, the possible effects of these new substances on the environment and living being began to make scientists think. As a result of this, the number of nanotoxicological studies started to increase [1-7]. The National Nano Initiative Program of the United States emphasized the need to increase the knowledge about the impact of nanotechnology on environmental, social and, most importantly, human health. The environmental protection organization and a number of scientists give importance to the investigation of the possible toxic effects of nanoparticles and argue that the information that will warn the public in this direction should be accessible.

The basic components of the nanoparticles, such as shape, size, surface area, surface properties, surface load and the tendency to aggregate, constitute an important parameter in the use of nanoparticles for a variety of purposes, and play an important role in their diffusion and toxic potentials to the ecosystem and especially to all living systems including humans. The surface area significantly affects the reactivity of a particle. Nano-sized particles react more easily than other sizes and are taken into the cell. Natural and industrial nanoparticles can reach the human body from various entry points such as skin, lung, stomach and intestinal system due to the properties and biological activity of the particle. They can easily reach the tissues via capillaries and from there to organs, cells and cellular structures. The target organs

\footnotetext{
${ }^{*}$ Corresponding author

E-mail address: turkoglu@cumhuriyet.edu.tr
} 
are usually lung, liver, spleen and kidney, and they have a toxic effect on these organs. Apart from these organs, they are found in various structures such as mitochondria, nuclei and fibroblasts [8-11].

Because of the physical properties of the nanoparticles, they can induce the formation of reactive oxygen species in the cells, resulting in cell damage and even cell death [12]. It is thought that nanoparticles can enter the cell by binding to receptors on the cell surface by endocytosis or enter into the cell by non-endocytosis means $[13,14]$.

As we mentioned earlier, many nanoparticles are used for different purposes. However, in this study, we aimed to study the genotoxic and cytotoxic effects of 5 nanoparticles (Titanium dioxide, Silicon oxide, Zinc oxide, Copper oxide and aluminium oxide) with two different test systems considering our material and laboratory facilities. In particular, we have tried to select the nanoparticles in many products that are frequently used by people. Again, we preferred the test methods, which are easy to work, do not cost much and have a short working time considering our laboratory facilities.

Titanium dioxide $\left(\mathrm{TiO}_{2}\right)$ nanoparticulate is a naturally occurring mineral derived from titanium oxide. This substance is used in many products after purification. Titanium dioxide has been the most common application area of nanoparticles ever developed. It is located in many fields such as food, cosmetics, pharmaceutical, paint, plastic, paper. The toxic, genotoxic and ecotoxic studies with $\mathrm{TiO}_{2}$ are still scarce [15-21].

Silicon dioxide $\left(\mathrm{SiO}_{2}\right)$ or silicon is a chemical compound containing oxygen and silicon. From food to cosmetics, from drugs to the automotive industry, it is used in many areas. In recent years, the use of $\mathrm{SiO}_{2}$ in biomedical and biotechnological studies has increased. These nanoparticles are of great importance in the development of antibacterial materials due to their high surface activity and high adsorption ability. In response to such widespread use, studies with nano-silicon are less compared to other nanoparticles [22-28].

Zinc oxide ( $\mathrm{ZnO}$ ) nanoparticles are among the most commonly used nanoparticles because they have a wide application range ranging from personal care products to coatings and catalysts used in environmental improvement. Many studies conducted so far have investigated the genotoxic and cytotoxic effects of this material [29-32].

Copper oxide $(\mathrm{CuO})$ nanoparticles have semi-conductive properties. Due to these properties, gas sensors, catalyst, magnetic phase transitions are used in intermediates, superconductors and ceramic pigments. Also recently, especially in non-odorous socks, under the name of antimicrobial textile, hospital equipment, wood preservation and antifouling paint materials are used widely as additives [33]. However, studies have shown that it has a toxic effect [34-38].

Aluminum oxide $\left(\mathrm{Al}_{2} \mathrm{O}_{3}\right)$ nanoparticles are preferred in surface treatment sector due to their high hardness and high durability. In addition, it decreases the growth of microorganisms in foods and provides a long shelf life [39]. Since they are lighter than other metals and have high mechanical strength, they also play a role in the production of materials and mechanical parts used in aerospace. Although aluminum is not considered as a carcinogenic substance, aluminum products are classified as dangerous carcinogenic substances for human health by International Agency for Research on Cancer [40]. Studies with this nanoparticle are limited in number and genotoxicity studies are very few [40-43].

A.cepa is a plant species commonly used to evaluate the mutagenic effects of environmental pollutants and chemicals. High-rise plants are quite common for cytogenotic analysis due to the size of their chromosomes. This test is an easy and inexpensive test and has a good correlation with mammalian test systems in particular [44]. Another model that we use in this study is $C$. elegans. This nematode is an organism commonly used in genetic studies, especially in the study of genetic control of development. The reason for the suitability of the research is that the hermaphroditic adult contains exactly 959 cells and each of these cells can be transformed into specific embryonic roots. The genetic characteristics of the organism are well known and the genome sequence is determined $[45,46]$. Bioimformatics analyzes the human with $60-80 \%$ of the genes of the worms reveals that it is homologous [47]. One of the indicators used to evaluate the biocompatibility and effects of nanoparticles in C.elegans is physiological evaluation. Lifetime and mortality rate play an important role in this evaluation $[10,48,49]$. the main way of getting nanoparticles to the $C$. elegans is the digestive systems; the worms are actively taken nanoparticles during feeding. Nanoparticles can also enter into the nematode by passive diffusion. Therefore, C.elegans offers promising features and tools to assess topical and oral nanoparticles before moving to more complex, model organisms.

As summarized above, nanoparticles have been widely used in many areas in recent years. Therefore, people began to be exposed to these nanoparticles both during production and during their use. In addition, these products are thrown into nature both during production and after use, thus making it mandatory for all living things in the world to come into contact with these nanoparticles. And a small number of short-term studies have shown that the majority of these nanoparticles have genotoxic effects on a wide variety of cells and organisms. Therefore, it is aimed to examine the toxic 
and genotoxic effects of titanium dioxide, silicon dioxide, zinc oxide, copper oxide and aluminum oxide nanoparticles in A. cepa and C. elegans, which we have encountered very frequently in our daily lives, but which we do not even know about.

\section{Material and methods}

In this study, 3 different concentrations were determined by examining the doses of the previous studies and all concentrations were suspended in distilled water and sonicated for 30 minutes in ultrasonic bath.

The density and size properties of the used nanoparticles are as follows.

$\mathrm{TiO}_{2}: 99.9 \%, 30 \mathrm{~nm}$

(CAS NO: 13463-67-7)

$\mathrm{SiO}_{2}: 99 \%, 20-30 \mathrm{~nm}$

(CAS NO: 7631-86-9)

ZnO: $99 \%, 10-30 \mathrm{~nm}$

(CAS NO: 1314-13-2)

CuO: $99 \%, 40 \mathrm{~nm}$

(CAS NO: 1317-38-0)

$\mathrm{AL}_{2} \mathrm{O}_{3}: 99 \%, 20 \mathrm{~nm}$

(CAS NO: 1344-28-1)

A. сера $L$., which used as a test material in the study, was left to germinate for 3 days in room temperature. The $A$. cepa root tips were treated with the 25, 50 and $100 \mu \mathrm{g}$ doses of the nanoparticles that we choose for 12 and 24 hours. And in the control group, only pure water was used. At the end of this period, $A$. cepa roots were cut with a razer from a point close to the tip, and fixated in 3:1 ethanol-glacial acetic acid for 24 hours. After that, hydrolysis was made in $1 \mathrm{~N} \mathrm{HCI}$ in order to provide that the cell walls to degrade, and after it is dyed with orcein, squash slide was made. At least 5000 cells were count for every dose and control by taking photos under the microscope.

C. elegans that we used in the study were provided from Cumhuriyet University Faculty of Medicine Parasitology department. The survival percent of the used nanoparticles in C. elegans, their length of life and their effects on physical growth was made with some modifications that are realized with the method used by Pirinç and Türkoğlu [50].

The studies were repeated 3 times, averages were determined and the differences between groups compared statistically with SPSS (SPSS 15.0) program and the evaluations were made as Average \pm Standard error.

\section{Results and discussion}

\subsection{Effects on Mitotic Index and Chromosomes in A. cepa}

\subsection{1. $\mathrm{TiO}_{2}$}

The total cell number that examined and mitotic phase ratios as a result of 25,50 and $100 \mu \mathrm{g} / \mathrm{ml} \mathrm{doses} \mathrm{of} \mathrm{TiO}_{2}$ nanoparticle to A. cepa root tip cells for 12 and 24 hours is seen in Table 1 . When we look at the 12 and 24 hour treatments, it is seen that there is a significant statistical difference between all doses and control group. When the effects of the same nanoparticle on chromosomes were examined, it is determined that the rate of chromosomal anomaly was increased in all doses and periods compared to control. It was observed that this increase of anomaly generally parallels to the dose increase (Table 2). The chromosome anomalies that $\mathrm{TiO}_{2}$ nanoparticle causes were determined as multinuclei, anaphase bridge, stickiness, break, laggard chromosome, irregular dispersion and binuclei. The rates of the chromosome anomalies, which found as a result of the made calculations, from the highest to the lowest are as follows; Binuclei $>$ Multinuclei $>$ C-mitosis $>$ Anaphase bridge $>$ Stickiness $>$ Irregular Dispersion $>$ Break $>$ Laggard Chromosome.

\subsection{2. $\mathrm{SiO}_{2}$}

The mitotic index rates obtained as a result of treating this nanoparticle to $A$. cepa root tip cells with same durations and doses is seen in Table 3. It was determined with the examinations that the mitotic index was decreased in 12 and 24 hours treatments times compared to the control. The types and the rates of the chromosome anomalies that observed after the treatment of silicium dioxide nanoparticle to A. cepa root tips is given in Table 4 . According to this, the highest observed chromosomal anomaly is binuclei. This is followed by C-mitosis, stickiness, anaphase bridge, laggard 
chromosome and irregular dispersion. When the table is examined, it is seen that the rate of chromosome anomaly increases in parallel with the dose and time inc3.1rease.

\subsection{3. $\mathrm{ZnO}$}

In the Table 5, mitotic index and mitotic phase rates observed after the treatment of zinc oxide is given. In the 12 hours treatment period, while the mitotic index ratio is $8.56 \mathrm{in}$ the control group, it was decreased to $3.82 \mathrm{in} 100 \mu \mathrm{g} / \mathrm{ml}$ group. In the statistical analysis between the groups in the time of this practice, significant differences were observed between control group and the other groups.

The effect of the same substance on the chromosomes and the obtained data are given in the Table 6. According to these data, the highest observed in the both treatment time and in all doses is binuclei. In addition to this anomaly, C-mitosis and multinuclei were observed highly. And in lesser amounts anaphase bridge, stickiness, laggard chromosome and irregular dispersion were seen. Also, in the examination that made, it is determined that the rate in chromosomal anomalies were increased as parallel to dose and treatment time.

\subsection{4. $\mathrm{CuO}$}

In Table 7, the mitotic index rates of $A$. cepa root tip cells treated with copper oxide are seen. In the both treatment times and in all doses, it is determined that mitotic index decreases compared to control. The anomalies that copper oxide nanoparticle created in A. cepa root tip cells and their rates are seen in Table 8. Like in the other nanoparticles, the most common anomaly is binuclei in copper oxide also. This is followed by C-mitosis, multinuclei, stickiness, laggard chromosome, anaphase bridge and irregular dispersion. As it can be understood from the table, the rates of these anomalies were increased as parallel to the dose and treatment time increase.

\subsection{5. $\mathrm{AL}_{2} \mathrm{O}_{3}$}

The mitotic phase and mitotic index rates of $A$. cepa root tip cells treated with aluminum oxide are seen in Table 9 . In the detailed examinations that made, a statistically significant difference is observed in all the doses except in 12 hours treatment with 25 and $100 \mu \mathrm{g} / \mathrm{ml}$ doses. And in 24 hours treatment, it is determined that there is a significant difference between all doses. In the Table 10, it is seen that the chromosomal anomalies, numbers and total abnormal cell rates in A. сера roots are seen. And in this nanoparticle treatment, a high rate of binuclei formation was observed. This is followed by multinuclei and C-mitosis. In addition, anaphase bridge, stickiness and irregular dispersion was detected in lesser amounts. Also, it is determined that the formed anomalies were realized in parallel to the dose and time increase.

\subsection{Effects on Longevity (the length of life), Egg production and Physical Growth in C. elegans}

\subsection{1. $\mathrm{TiO}_{2}$}

The length of life obtained as a result of different doses of titanium dioxide nanoparticle to $C$. elegans nematode is seen in Figure 1. In the control group, the survival percent completed in 17 days ended on day 16 in $25 \mu \mathrm{g} / \mathrm{ml}$ treatment, on day 15 at $50 \mu \mathrm{g} / \mathrm{ml}$ dose and on day 13 at $100 \mu \mathrm{g} / \mathrm{ml}$ dose. In general, a decrease in the length of life due to dose increase was determined. When the effect of the same substance on hatching rate was examined, it was determined that there were 125 babies out of 139 eggs. The data of the research are shown in Table 11.

When we look at the physical growth data of titanium dioxide (Table 12), the value of $4.99 \mathrm{~mm}$ measured in the control group was determined as $3.95 \mathrm{in} 25 \mu \mathrm{g} / \mathrm{ml}, 3.66$ at $50 \mu \mathrm{g} / \mathrm{ml}$ and $2.38 \mathrm{~mm}$ at $100 \mu \mathrm{g} / \mathrm{ml}$. It is observed that the substance used suppresses physical growth and this is statistically significant (for $100 \mu \mathrm{g} / \mathrm{ml}$ ).

\subsection{2. $\mathrm{SiO}_{2}$}

Rates about the length of life, egg yield and physical growth in C. elegans treated with silicium dioxide are given in Figure 2. While the length of life is 17 days in control and $25 \mu \mathrm{g} / \mathrm{ml}$ doses, it is 12 days in $100 \mu \mathrm{g} / \mathrm{ml}$ dose. When all the doses were examined, it was seen that the decrease in the length of life was parallel to the dose increase. The effects of this nanoparticle on the hatching can be seen in Table 11. While in the control group, there were 131 babies out of 134 eggs and in silisium dioxide there were 110 babies out of 124 eggs. In statistical evaluations, it was determined that there is a statistical significance between the control group and the treatment group. When the physical growth data of the same substance were examined, it was determined that there is a decrease compared to the control group and this situation was parallel to the dose increase (Table 12). 
Table 1 The effects of $\mathrm{TiO}_{2}$ on mitotic index and mitotic phases in the root cells of $A$. cepa

\begin{tabular}{llllllll}
\hline $\begin{array}{l}\text { Time } \\
\text { (hours) }\end{array}$ & $\begin{array}{l}\text { Doses } \\
(\boldsymbol{\mu g} / \mathbf{m l})\end{array}$ & $\begin{array}{l}\text { Counted } \\
\text { numbers }\end{array}$ & $\begin{array}{l}\text { cell } \\
\text { numbers }\end{array}$ & $\begin{array}{l}\text { Divided cell Prophase } \\
\text { numbetaphase }\end{array}$ & $\begin{array}{l}\text { Anaphase- } \\
\text { telophase }\end{array}$ \\
\hline & Control & 5020 & 430 & 300 & 85 & 45 \\
Mean \pm SD*
\end{tabular}

Table 2 Percentage of chromosomal aberrations of $\mathrm{TiO}_{2}$ at different times and concentrations obtained for the Allium test

\begin{tabular}{|c|c|c|c|c|c|c|c|c|c|c|c|c|}
\hline $\begin{array}{l}\text { Time } \\
\text { (hours) }\end{array}$ & $\begin{array}{l}\text { Doses } \\
(\mu \mathrm{g} / \mathrm{ml})\end{array}$ & $\begin{array}{l}\text { Divided } \\
\text { cell } \\
\text { numbers }\end{array}$ & Cmitosis & $\begin{array}{l}\text { Multi } \\
\text { nucleus }\end{array}$ & $\begin{array}{l}\text { Anaphase } \\
\text { bridge }\end{array}$ & Sticky & Break & Laggard & $\begin{array}{l}\text { Irregular } \\
\text { Dispersion }\end{array}$ & Binucleus & $\begin{array}{l}\text { Total } \\
\text { anomalies } \\
\text { numbers }\end{array}$ & $\begin{array}{l}\text { Total } \\
\text { anomalies } \\
(\%)\end{array}$ \\
\hline \multirow{4}{*}{12} & Control & 430 & - & - & - & - & - & - & - & 25 & 25 & 0,48 \\
\hline & 25 & 191 & 20 & 58 & 1 & - & 1 & - & 2 & 30 & 112 & 2,23 \\
\hline & 50 & 214 & 33 & 42 & 10 & 7 & 1 & 2 & 5 & 96 & 196 & 3,91 \\
\hline & 100 & 195 & 56 & 18 & 2 & 9 & 2 & 1 & 3 & 238 & 358 & 7,11 \\
\hline \multirow{4}{*}{24} & Control & 452 & - & - & - & - & - & - & - & 34 & 34 & 0,67 \\
\hline & 25 & 202 & 27 & 70 & 3 & 1 & 4 & 3 & - & 20 & 138 & 2,71 \\
\hline & 50 & 192 & 15 & 124 & 15 & 4 & 2 & - & 3 & 220 & 388 & 7,54 \\
\hline & 100 & 180 & 54 & 171 & 14 & 9 & 2 & 6 & 1 & 206 & 463 & 9,00 \\
\hline
\end{tabular}


Table 3 The effects of $\mathrm{SiO}_{2}$ on mitotic index and mitotic phases in the root cells of $A$. cepa

\begin{tabular}{|c|c|c|c|c|c|c|c|}
\hline $\begin{array}{l}\text { Time } \\
\text { (hours) }\end{array}$ & $\begin{array}{l}\text { Doses } \\
(\mu \mathrm{g} / \mathrm{ml})\end{array}$ & $\begin{array}{l}\text { Counted cell } \\
\text { numbers }\end{array}$ & $\begin{array}{l}\text { Divided cell } \\
\text { numbers }\end{array}$ & Prophase & Metaphase & $\begin{array}{l}\text { Anaphase- } \\
\text { telophase }\end{array}$ & $\begin{array}{l}\text { Mitotic index } \\
\text { Mean } \pm S D^{*}\end{array}$ \\
\hline \multirow{4}{*}{12} & Control & 5020 & 430 & 300 & 85 & 45 & $8,56 \pm 0,42 \mathrm{a}$ \\
\hline & 25 & 5112 & 253 & 164 & 44 & 45 & $4,94 \pm 0,70 \mathrm{~b}$ \\
\hline & 50 & 5027 & 199 & 134 & 43 & 22 & $3,95 \pm 1,12 \mathrm{c}$ \\
\hline & 100 & 5194 & 172 & 124 & 57 & 24 & $3,31 \pm 1,17 \mathrm{c}$ \\
\hline \multirow{4}{*}{24} & Control & 5048 & 452 & 301 & 59 & 92 & $8,95 \pm 0,32 \mathrm{a}$ \\
\hline & 25 & 5137 & 203 & 136 & 39 & 28 & $3,95 \pm 0,63 b$ \\
\hline & 50 & 5114 & 169 & 134 & 9 & 26 & $3,30 \pm 1,98 \mathrm{~b}$ \\
\hline & 100 & 5026 & 160 & 114 & 23 & 23 & $3,18 \pm 1,05 \mathrm{c}$ \\
\hline
\end{tabular}

${ }^{*}$ Means with the same letter do not differ statistically at the level of 0,05 , Mean \pm SD: Mean \pm Standard deviation

Table 4 Percentage of chromosomal aberrations of $\mathrm{SiO}_{2}$ at different times and concentrations obtained for the Allium test

\begin{tabular}{|c|c|c|c|c|c|c|c|c|c|c|}
\hline $\begin{array}{l}\text { Time } \\
\text { (hours) }\end{array}$ & $\begin{array}{l}\text { Doses } \\
(\mu \mathrm{g} / \mathrm{ml})\end{array}$ & $\begin{array}{l}\text { Divided } \\
\text { cell } \\
\text { numbers }\end{array}$ & Cmitosis & $\begin{array}{l}\text { Anaphase } \\
\text { bridge }\end{array}$ & Sticky & Laggard & $\begin{array}{l}\text { Irregular } \\
\text { Dispersion }\end{array}$ & Binucleus & $\begin{array}{l}\text { Total } \\
\text { anomalies } \\
\text { numbers }\end{array}$ & $\begin{array}{l}\text { Total } \\
\text { anomalies } \\
(\%)\end{array}$ \\
\hline \multirow{4}{*}{12} & Control & 430 & - & - & - & - & - & 25 & 25 & 0,48 \\
\hline & 25 & 253 & 6 & - & 2 & - & - & 150 & 158 & 3,09 \\
\hline & 50 & 199 & 15 & 2 & 5 & 1 & - & 275 & 298 & 5,92 \\
\hline & 100 & 172 & 38 & 1 & 5 & 3 & 1 & 320 & 368 & 7.08 \\
\hline \multirow{4}{*}{24} & Control & 452 & - & - & - & - & - & 34 & 34 & 0,67 \\
\hline & 25 & 203 & 8 & 4 & 3 & - & 1 & 262 & 278 & 5,41 \\
\hline & 50 & 169 & 32 & 3 & - & - & - & 350 & 385 & 7,52 \\
\hline & 100 & 160 & 37 & 3 & 5 & 3 & 3 & 361 & 412 & 8,19 \\
\hline
\end{tabular}


Table 5 The effects of $\mathrm{ZnO}$ on mitotic index and mitotic phases in the root cells of $A$. cepa

\begin{tabular}{|c|c|c|c|c|c|c|c|}
\hline Time (hours) & $\begin{array}{l}\text { Doses } \\
(\mu \mathrm{g} / \mathrm{ml})\end{array}$ & $\begin{array}{l}\text { Counted cell } \\
\text { numbers }\end{array}$ & $\begin{array}{l}\text { Divided cell } \\
\text { numbers }\end{array}$ & Prophase & Metaphase & $\begin{array}{l}\text { Anaphase- } \\
\text { telophase }\end{array}$ & $\begin{array}{l}\text { Mitotic index } \\
\text { Mean } \pm S D^{*}\end{array}$ \\
\hline \multirow{4}{*}{12} & Control & 5020 & 430 & 300 & 85 & 45 & $8,56 \pm 0,55 \mathrm{a}$ \\
\hline & 25 & 5030 & 338 & 175 & 90 & 73 & $6,72 \pm 0,49 \mathrm{~b}$ \\
\hline & 50 & 5015 & 282 & 170 & 35 & 80 & $5,62 \pm 0,61 \mathrm{c}$ \\
\hline & 100 & 5146 & 197 & 160 & 22 & 15 & $3,82 \pm 1,01 \mathrm{~d}$ \\
\hline \multirow{4}{*}{24} & Control & 5048 & 452 & 301 & 59 & 92 & $8,95 \pm 1,23 \mathrm{a}$ \\
\hline & 25 & 5160 & 335 & 180 & 140 & 15 & $6,49 \pm 0,13 \mathrm{~b}$ \\
\hline & 50 & 5070 & 196 & 96 & 78 & 22 & $3,86 \pm 0,87 \mathrm{c}$ \\
\hline & 100 & 5107 & 153 & 98 & 13 & 42 & $3,17 \pm 0,41 \mathrm{c}$ \\
\hline
\end{tabular}

Table 6 Percentage of chromosomal aberrations of $\mathrm{ZnO}$ at different times and concentrations obtained for the Allium test

\begin{tabular}{|c|c|c|c|c|c|c|c|c|c|c|c|}
\hline $\begin{array}{l}\text { Time } \\
\text { (hours) }\end{array}$ & $\begin{array}{l}\text { Doses } \\
(\mu \mathrm{g} / \mathrm{ml})\end{array}$ & $\begin{array}{l}\text { Divided } \\
\text { cell } \\
\text { numbers }\end{array}$ & Cmitosis & $\begin{array}{l}\text { Multi } \\
\text { nucleus }\end{array}$ & $\begin{array}{l}\text { Anaphase } \\
\text { bridge }\end{array}$ & Sticky & Laggard & $\begin{array}{l}\text { Irregular } \\
\text { Dispersion }\end{array}$ & Binucleus & $\begin{array}{l}\text { Total } \\
\text { anomalies } \\
\text { numbers }\end{array}$ & $\begin{array}{l}\text { Total } \\
\text { anomalies } \\
(\%)\end{array}$ \\
\hline \multirow{4}{*}{12} & Control & 430 & - & - & - & - & - & - & 25 & 25 & 0,48 \\
\hline & 25 & 338 & 9 & - & - & - & - & - & 183 & 192 & 3,81 \\
\hline & 50 & 282 & 7 & - & - & - & - & - & 200 & 207 & 4,12 \\
\hline & 100 & 197 & 32 & - & 1 & - & - & 1 & 246 & 248 & 4,81 \\
\hline \multirow{4}{*}{24} & Control & 452 & - & - & - & - & - & - & 34 & 34 & 0,67 \\
\hline & 25 & 335 & 25 & 8 & 2 & 2 & - & - & 200 & 237 & 4,59 \\
\hline & 50 & 196 & 13 & 24 & 1 & 1 & 1 & - & 320 & 360 & 7,10 \\
\hline & 100 & 153 & 15 & 56 & - & 1 & - & - & 355 & 427 & 8,36 \\
\hline
\end{tabular}


Table 7 The effects of $\mathrm{CuO}$ on mitotic index and mitotic phases in the root cells of $A$. cepa

\begin{tabular}{|c|c|c|c|c|c|c|c|c|c|}
\hline $\begin{array}{l}\text { Time } \\
\text { (hours) }\end{array}$ & $\begin{array}{l}\text { Doses } \\
(\mu \mathrm{g} / \mathrm{ml})\end{array}$ & $\begin{array}{l}\text { Counted } \\
\text { numbers }\end{array}$ & cell & $\begin{array}{l}\text { Divided } \\
\text { numbers }\end{array}$ & cell & Prophase & Metaphase & $\begin{array}{l}\text { Anaphase- } \\
\text { telophase }\end{array}$ & $\begin{array}{l}\text { Mitotic index } \\
\text { Mean } \pm S D^{*}\end{array}$ \\
\hline \multirow{4}{*}{12} & Control & 5020 & & 430 & & 300 & 85 & 45 & $8,56 \pm 0,19$ a \\
\hline & 25 & 5005 & & 303 & & 163 & 75 & 65 & $6,05 \pm 1,27 b$ \\
\hline & 50 & 5038 & & 206 & & 159 & 12 & 35 & $4,08 \pm 0,93 \mathrm{c}$ \\
\hline & 100 & 5148 & & 183 & & 151 & 19 & 13 & $3,55 \pm 0,72 \mathrm{~d}$ \\
\hline \multirow{4}{*}{24} & Control & 5048 & & 452 & & 301 & 59 & 92 & $8,95 \pm 0,45 \mathrm{a}$ \\
\hline & 25 & 5152 & & 210 & & 145 & 20 & 23 & $4,07 \pm 0,66 b$ \\
\hline & 50 & 5064 & & 177 & & 140 & 15 & 22 & $3,49 \pm 1,03 \mathrm{c}$ \\
\hline & 100 & 5007 & & 159 & & 102 & 14 & 43 & $3,17 \pm 0,41 \mathrm{c}$ \\
\hline
\end{tabular}

Table 8 Percentage of chromosomal aberrations of $\mathrm{CuO}$ at different times and concentrations obtained for the Allium test

\begin{tabular}{|c|c|c|c|c|c|c|c|c|c|c|c|}
\hline $\begin{array}{l}\text { Time } \\
\text { (hours) }\end{array}$ & $\begin{array}{l}\text { Doses } \\
(\mu \mathrm{g} / \mathrm{ml})\end{array}$ & $\begin{array}{l}\text { Divided } \\
\text { cell } \\
\text { numbers }\end{array}$ & Cmitosis & $\begin{array}{l}\text { Multi } \\
\text { nucleus }\end{array}$ & $\begin{array}{l}\text { Anaphase } \\
\text { bridge }\end{array}$ & Sticky & Laggard & $\begin{array}{l}\text { Irregular } \\
\text { Dispersion }\end{array}$ & Binucleus & $\begin{array}{l}\text { Total } \\
\text { anomalies } \\
\text { numbers }\end{array}$ & $\begin{array}{l}\text { Total } \\
\text { anomalies } \\
(\%)\end{array}$ \\
\hline & Control & 430 & - & - & - & - & - & - & 25 & 25 & 0,48 \\
\hline & 25 & 303 & 13 & - & - & - & - & - & 172 & 185 & 3,67 \\
\hline & 50 & 206 & 16 & - & - & - & 1 & - & 270 & 287 & 5,69 \\
\hline & 100 & 183 & 32 & - & 1 & - & - & 1 & 390 & 392 & 7,61 \\
\hline \multicolumn{12}{|l|}{12} \\
\hline & Control & 452 & - & - & - & - & - & - & 34 & 34 & 0,67 \\
\hline & 25 & 210 & 44 & 15 & 2 & 2 & 1 & - & 299 & 314 & 6,09 \\
\hline & 50 & 177 & 24 & 37 & 1 & 4 & 3 & 3 & 340 & 415 & 8,19 \\
\hline 24 & 100 & 159 & 36 & 73 & - & 1 & - & - & 403 & 513 & 10,24 \\
\hline
\end{tabular}


Table 9 The effects of $\mathrm{Al}_{2} \mathrm{O}_{3}$ on mitotic index and mitotic phases in the root cells of $A$. cepa

\begin{tabular}{|c|c|c|c|c|c|c|c|c|c|}
\hline $\begin{array}{l}\text { Time } \\
\text { (hours) }\end{array}$ & $\begin{array}{l}\text { Doses } \\
(\mu \mathrm{g} / \mathrm{ml})\end{array}$ & $\begin{array}{l}\text { Counted } \\
\text { numbers }\end{array}$ & cell & $\begin{array}{l}\text { Divided } \\
\text { numbers }\end{array}$ & cell & Prophase & Metaphase & $\begin{array}{l}\text { Anaphase- } \\
\text { telophase }\end{array}$ & $\begin{array}{l}\text { Mitotic index } \\
\text { Mean } \pm S D^{*}\end{array}$ \\
\hline \multirow{4}{*}{12} & Control & 5020 & & 430 & & 300 & 85 & 45 & $8,56 \pm 1,56 \mathrm{a}$ \\
\hline & 25 & 5033 & & 341 & & 180 & 93 & 68 & $6,77 \pm 0,91 \mathrm{~b}$ \\
\hline & 50 & 5007 & & 304 & & 175 & 43 & 86 & $6,07 \pm 1,23 \mathrm{~b}$ \\
\hline & 100 & 5145 & & 223 & & 165 & 33 & 25 & $4,33 \pm 0,62$ c \\
\hline \multirow{4}{*}{24} & Control & 5048 & & 452 & & 301 & 59 & 92 & $8,95 \pm 1,03$ a \\
\hline & 25 & 5167 & & 289 & & 168 & 65 & 56 & $5,59 \pm 0,72 \mathrm{~b}$ \\
\hline & 50 & 5005 & & 208 & & 123 & 63 & 22 & $4,15 \pm 0,69 \mathrm{c}$ \\
\hline & 100 & 5134 & & 189 & & 95 & 56 & 38 & $3,68 \pm 1,42 \mathrm{~d}$ \\
\hline
\end{tabular}

${ }^{*}$ Means with the same letter do not differ statistically at the level of 0,05, Mean \pm SD: Mean \pm Standard deviation

Table 10 Percentage of chromosomal aberrations of $\mathrm{Al}_{2} \mathrm{O}_{3}$ at different times and concentrations obtained for the Allium test

\begin{tabular}{|c|c|c|c|c|c|c|c|c|c|c|}
\hline $\begin{array}{l}\text { Time } \\
\text { (hours) }\end{array}$ & $\begin{array}{l}\text { Doses } \\
(\mu \mathrm{g} / \mathrm{ml})\end{array}$ & $\begin{array}{l}\text { Divided } \\
\text { cell } \\
\text { numbers }\end{array}$ & Cmitosis & $\begin{array}{l}\text { Multi } \\
\text { nucleus }\end{array}$ & $\begin{array}{l}\text { Anaphase } \\
\text { bridge }\end{array}$ & Sticky & $\begin{array}{l}\text { Irregular } \\
\text { Dispersion }\end{array}$ & Binucleus & $\begin{array}{l}\text { Total } \\
\text { anomalies } \\
\text { numbers }\end{array}$ & $\begin{array}{l}\text { Total } \\
\text { anomalies } \\
(\%)\end{array}$ \\
\hline \multirow{4}{*}{12} & Control & 430 & - & - & - & - & - & 25 & 25 & 0,48 \\
\hline & 25 & 341 & 4 & - & - & - & - & 176 & 180 & 3,57 \\
\hline & 50 & 304 & 3 & - & - & - & - & 234 & 237 & 4,73 \\
\hline & 100 & 223 & 17 & - & 1 & - & 1 & 246 & 265 & 5,15 \\
\hline \multirow{4}{*}{24} & Control & 452 & - & - & - & - & - & 34 & 34 & 0,67 \\
\hline & 25 & 289 & 15 & 8 & 2 & 1 & - & 204 & 230 & 4,45 \\
\hline & 50 & 208 & 13 & 34 & 1 & 1 & - & 234 & 283 & 5,65 \\
\hline & 100 & 189 & 15 & 43 & - & 1 & - & 342 & 401 & 7,81 \\
\hline
\end{tabular}




\subsection{3. $\mathrm{ZnO}$}

The effects of zinc oxide nanoparticle on length of life (Figure 3), egg percentage (Table 11) and physical growth (Table 12 ) in C. elegans were examined. While the length of life is 17 days in control group, it is 15 days in $25 \mu \mathrm{g} / \mathrm{ml} \mathrm{dose}, 9$ days in $50 \mu \mathrm{g} / \mathrm{ml}$ dose and 7 days in $100 \mu \mathrm{g} / \mathrm{ml}$ dose. While the egg yield is $98.51 \%$ in control group, it was decreased to $93.87 \%$ in zinc oxide and this is statistically important. When the physical growth rates are looked, while it is 4.99 in the control group, it was determined as $3.03 \mathrm{in} 25 \mu \mathrm{g} / \mathrm{ml}, 2.40 \mathrm{in} 50 \mu \mathrm{g} / \mathrm{ml}$ and $1.92 \mathrm{in} 100 \mu \mathrm{g} / \mathrm{ml}$. It is seen that, in parallel with the dose increase, there is a decline in physical growth.

\subsection{4. $\mathrm{CuO}$}

The length of life data obtained as a result of different doses of copper dioxide nanoparticle to $C$. elegans nematode can be seen in Figure 4 While the length of life is 17 days in control group, it is 15 days in $25 \mu \mathrm{g} / \mathrm{ml} \mathrm{dose,} 12 \mathrm{days}$ in $50 \mu \mathrm{g} / \mathrm{ml}$ dose and 6 days in $100 \mu \mathrm{g} / \mathrm{ml}$ dose in the nematodes treated with copper oxide nanoparticle. When the hatching rates are examined, the average which is $98.51 \%$ in the control group is decreased to $85.27 \%$. It is seen that this situation is statistically significant (Table 11). When the effects of the same substance on physical growth is looked (Table 12) while it is 4.99 in the control group, it was determined as 3.73, 3.59 and 2.96 in other doses respectively. It was determined that this decline in physical growth occurred parallel to the dose increase.

\subsection{5. $\mathrm{AL}_{2} \mathrm{O}_{3}$}

The data obtained as a result of different doses of aluminum dioxide nanoparticle to C. elegans is given in Figure 5, Table 11 and Table 12. The length of life of the nematodes treated with the substance is 17 days in control group, while it is 16 days in $25 \mu \mathrm{g} / \mathrm{ml}$ dose, 9 days in $50 \mu \mathrm{g} / \mathrm{ml}$ dose and 7 days in $100 \mu \mathrm{g} / \mathrm{ml}$ dose. In the examinations made for the egg yield, while the $98.51 \%$ of the eggs were hatched in control group, $88.34 \%$ of them were hatched in the groups treated with aluminum oxide. The physical growth values of the hatched individuals were examined and the nematodes treated with substance were observed to be regressed.

Table 11 Effects of titanium dioxide, silicon dioxide, zinc oxide, copper oxide and aluminum oxide nanoparticles on egg percentage in C. elegans

\begin{tabular}{llll}
\hline Chemicals & Number of eggs & Egg yield & Percentage eggs \% \\
\hline Control & 134 & 131 & $98,51 \mathrm{a}$ \\
$\mathrm{TiO}_{2}$ & 139 & 125 & $89,69 \mathrm{~b}$ \\
$\mathrm{SiO}_{2}$ & 124 & 110 & $84,43 \mathrm{c}$ \\
$\mathrm{ZnO}$ & 132 & 124 & $93,87 \mathrm{~d}$ \\
$\mathrm{CuO}$ & 153 & 130 & $85,27 \mathrm{e}$ \\
$\mathrm{AL}_{2} \mathrm{O}_{3}$ & 133 & 118 & $88,34 \mathrm{f}$ \\
\hline \multicolumn{4}{c}{}
\end{tabular}

Table 12 Effects of titanium dioxide, silicon dioxide, zinc oxide, copper oxide and aluminum oxide nanoparticles on physical growth in C.elegans

\begin{tabular}{llllll}
\hline Doses & $\mathbf{T i O}_{2}$ & $\mathbf{S i O}_{2}$ & $\mathbf{Z n O}$ & $\mathbf{C u O}$ & $\mathbf{A L}_{2} \mathbf{O}_{3}$ \\
\hline Control & $4,99 \mathrm{a}$ & $4,99 \mathrm{a}$ & $4,99 \mathrm{a}$ & $4,99 \mathrm{a}$ & $4,99 \mathrm{a}$ \\
25 & $3,95 \mathrm{~b}$ & $3,70 \mathrm{~b}$ & $3,03 \mathrm{~b}$ & $3,73 \mathrm{~b}$ & $3,60 \mathrm{~b}$ \\
50 & $3,66 \mathrm{~b}$ & $2,65 \mathrm{c}$ & $2,40 \mathrm{c}$ & $3,59 \mathrm{~b}$ & $3,44 \mathrm{~b}$ \\
100 & $2,38 \mathrm{c}$ & $2,56 \mathrm{c}$ & $1,92 \mathrm{~d}$ & $2,96 \mathrm{c}$ & $2,63 \mathrm{c}$ \\
\hline \multicolumn{5}{c}{ Mean \pm SD: Mean \pm Standard deviation }
\end{tabular}




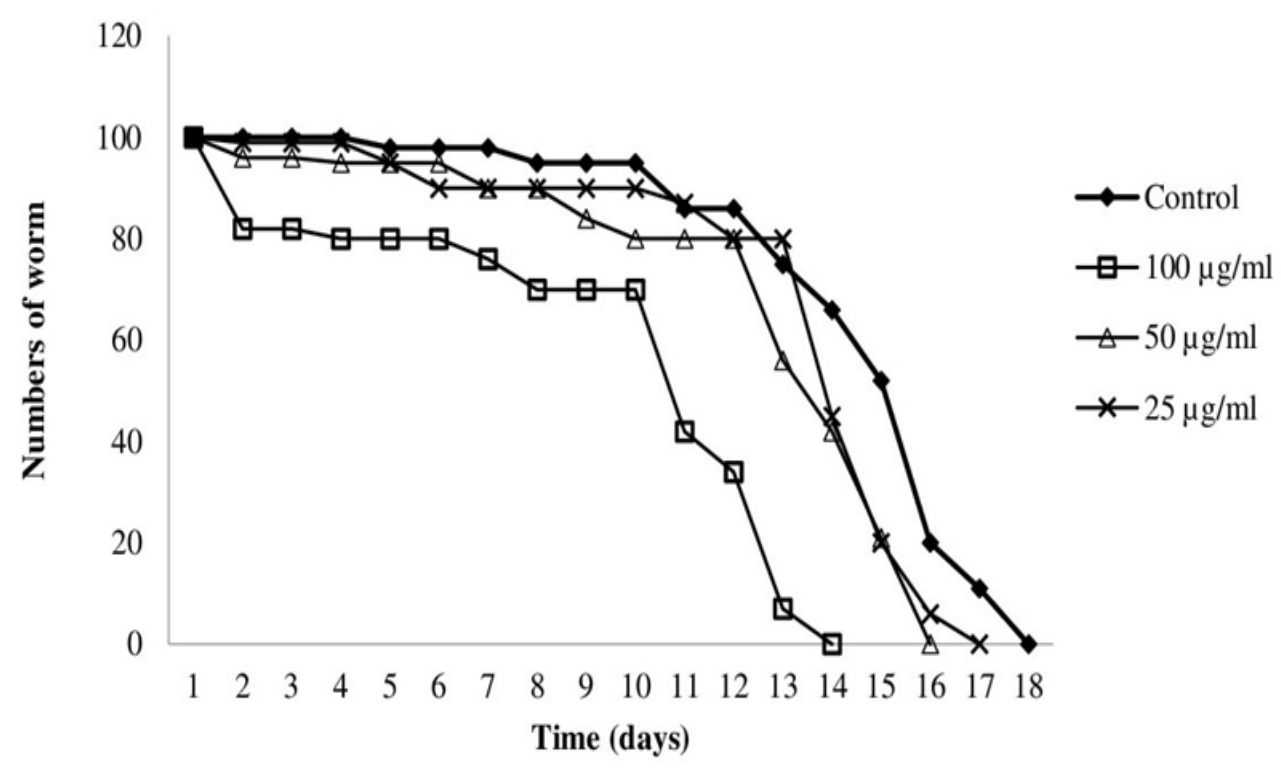

Figure 1 The effects of $\mathrm{TiO}_{2}$ on the life span of $C$. elegans

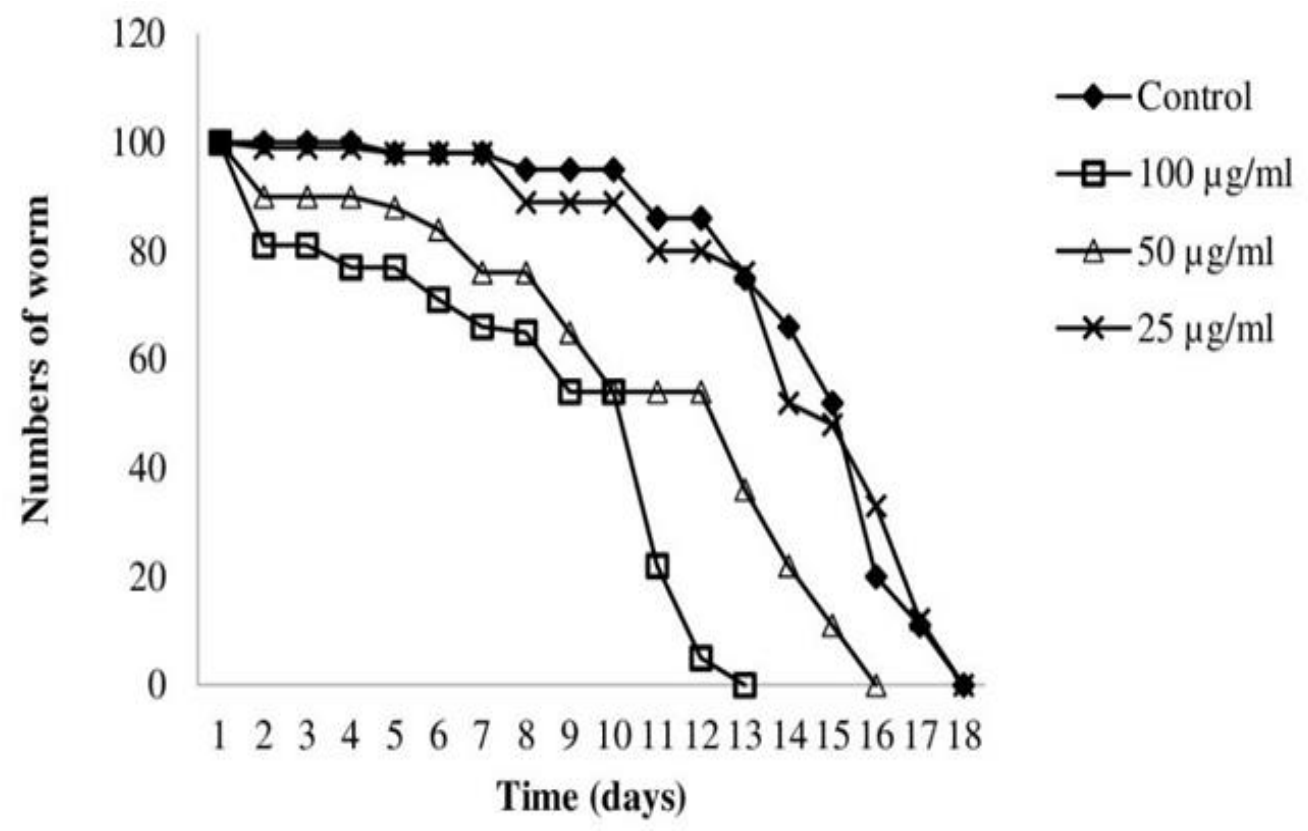

Figure 2 The effects of $\mathrm{SiO}_{2}$ on the life span of $C$. elegans 


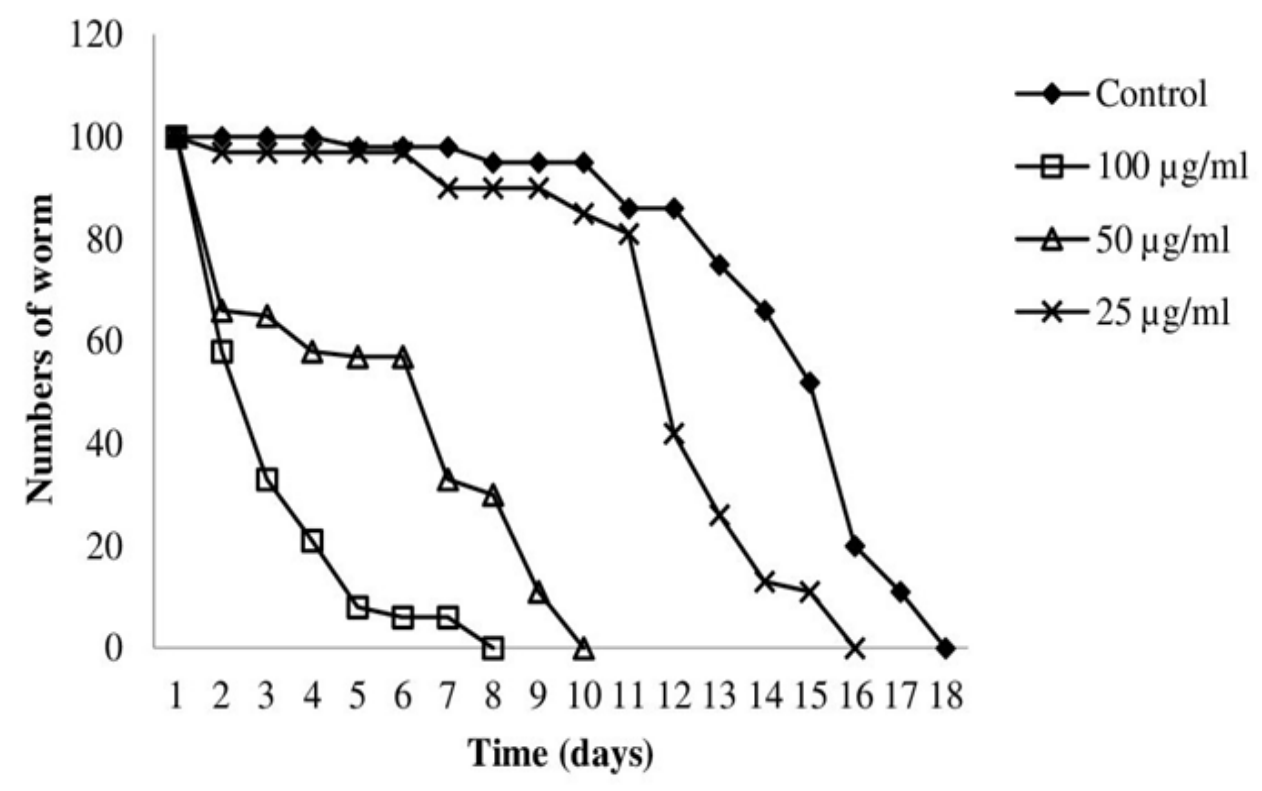

Figure 3 The effects of $\mathrm{ZnO}$ on the life span of $C$. elegans

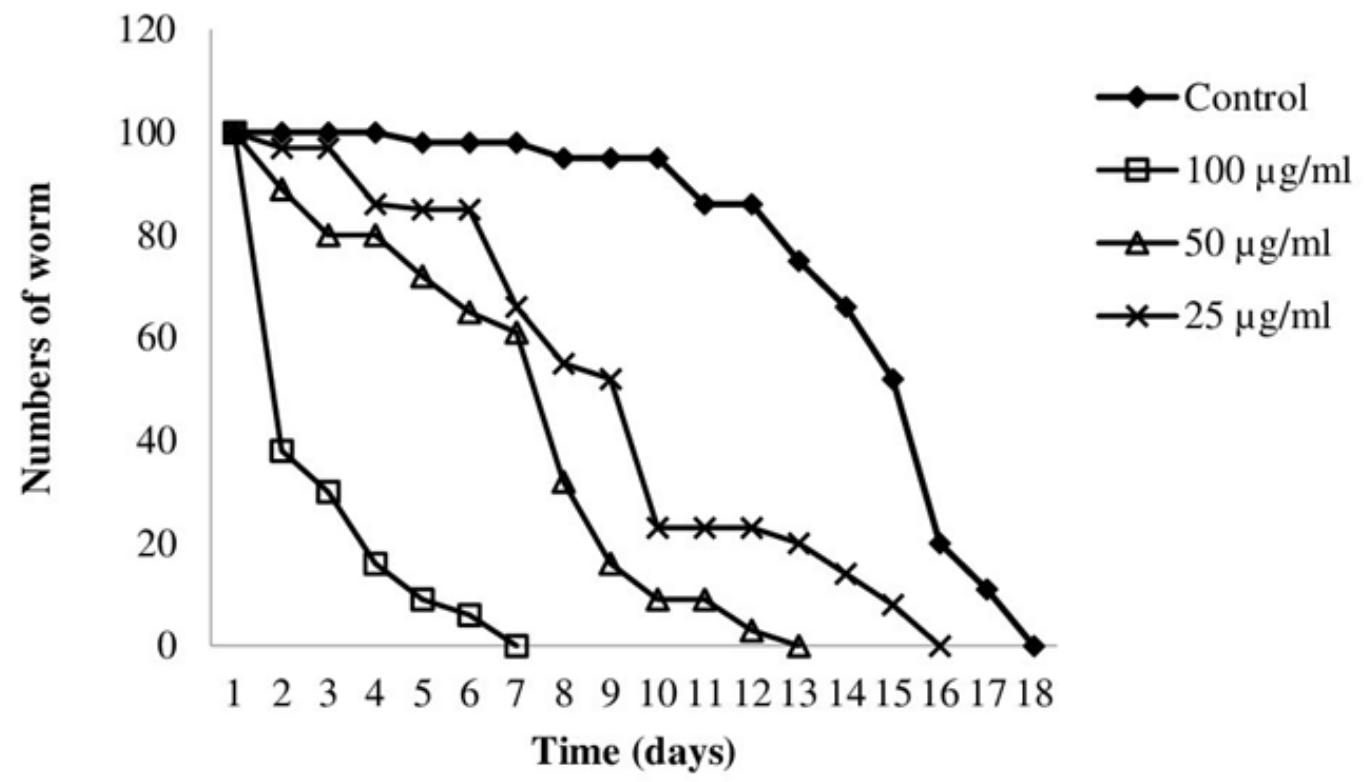

Figure 4 The effects of $\mathrm{CuO}_{2}$ on the life span of $C$. elegans 


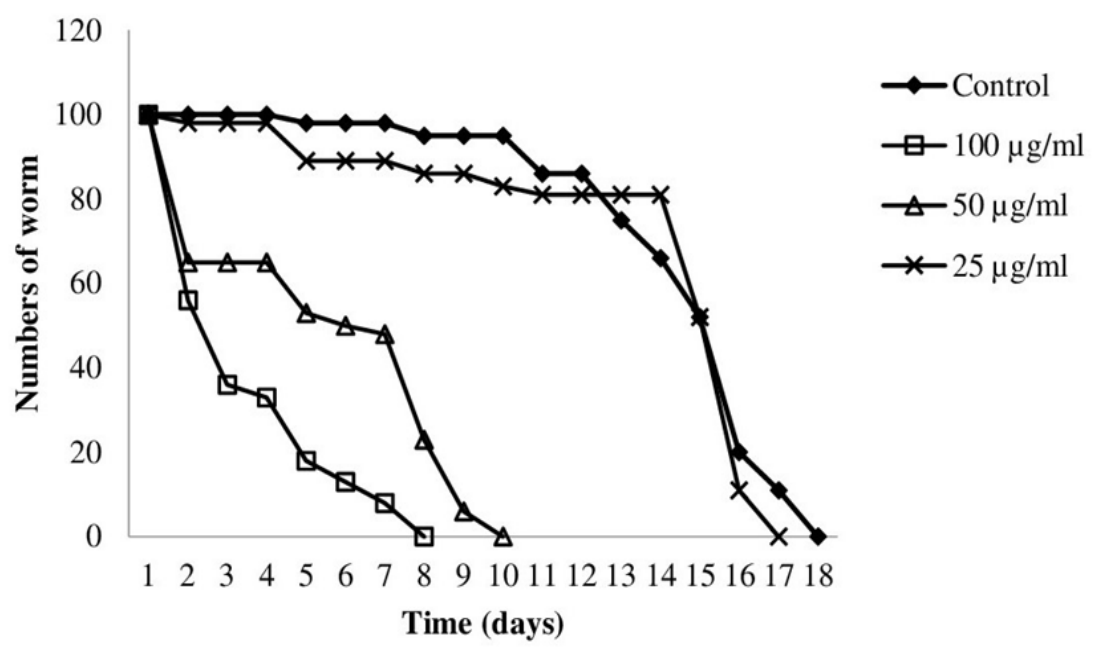

Figure 5 The effects of $\mathrm{Al}_{2} \mathrm{O}_{3}$ on the life span of $C$. elegans

\section{Discussion}

The effects of a wide range of nanoparticles on the environment and human health as a result of rapid progress in nanotechnology are unclear. There are studies that investigate the potential effects of these substances on the environment and humans, which take place in many areas, from defense industry to food, cosmetics to textiles, diagnosis of diseases to treatment, but many of us are unaware of the existence of these substances, but they are not sufficient. Nano scale materials can be taken into cells more easily than the larger size ones. As a result, the interactions within the cell and tissue are also higher. Factors such as shape, surface area, chemical structure of the surface, type of cell used, concentration and duration of application change the effects of these substances. Due to these parameters, studies on the toxic and genotoxic effects of nanoparticles have produced conflicting results. The toxicological reactions of nanoparticles depend on their activity in organelles such as the cytoplasm, nucleus, mitochondria, lysosomes they affect in the cell they reach. Cobalt chromosome alloys are widely used in orthopedic applications, filling and dental implants, cardiovascular surgery and especially in stenting applications. In genotoxicity studies conducted with these nanoparticles, it was determined that they moved away from the region they were applied to and moved to other regions and these nanoparticles were found in lymph nodes, blood, bone marrow, liver, urea and hair [51-53].

In vitro toxic mechanisms of action of nanoparticles can be classified as follows; damage to cell wall and plasma membrane, interaction with electron transport and aerobic respiration, induction of oxidative stress, activation in cell signaling pathway, deterioration in ion homeostasis, some release of toxic metal ions from nanoparticles, deterioration of lysosomal membrane integrity, failure of phagocytosis, inadequate intake, cell skeletal functions interaction, DNA and chromosomal damage [54].

In the first part of this study, the effects of titanium dioxide, copper oxide, zinc oxide, silicon dioxide and aluminum oxide nanoparticles on mitosis and chromosomes in A. cepa were investigated. The substances used were applied at different doses to $A$. cepa root tip cells for 12 and 24 hours and the results were examined. In light of the data obtained, it has been determined that these nanoparticles we use have decreased mitotic index in A. cepa compared to control. Mitotic index is considered as a parameter that provides estimation of cell division frequency. Reductions in the mitotic index can be attributed to mitotic inhibitions. Once a chemical substance comes into contact with cells and remains in the cell at critical concentrations, it can form an active form that causes disruption in the cell cycle. This adverse effect may increase gradually depending on the application period and stage [55].

The toxic effect of nanomaterials can cause serious damage to the DNA and slow the transitions in the cell cycle. Reduction in mitotic index is an indicator of decreased cell proliferation [56,57]. The cell cycle control points block the transition from $\mathrm{G} 1$ to $\mathrm{S}$ phase or from $\mathrm{G} 2$ to mitosis, depending on the site of damage in cells exposed to a toxic effective substance. A DNA damage can also inhibit DNA synthesis and thus RNA and protein synthesis. Inactivation of kinase complexes in non-replicated cells can prevent the introduction of mitosis $[57,58]$.

Reduction and increase in mitotic index in A. cepa cells are the most commonly used parameters. Reduction in mitotic index is considered as a marker of cytotoxicity. This reduction indicates that the growth and development of the plant 
is inhibited by the effect of the chemical being exposed. The increase observed in the mitotic index means irregular cell divisions and a tumorous tissue [59-63].

Allium test is a good marker for the detection of numerical and structural abnormalities in chromosomes other than mitotic index. These changes in the chromosomes can be spontaneous, or they can be generated by an exogenous stimulus. Structural disorders in the chromosome can be stimulated by many factors such as DNA fractures, inhibition of DNA synthesis and errors in DNA replication. Abnormalities in the number of chromosomes can be caused by the effects of the chemical substances on the mitotic spindles as well as the irregular separation of the chromosomes. Chromosomal abnormalities can occur in all cell stages. For this reason, Fiskesjö [44] emphasized that all stages should be taken into consideration in the examination and evaluation.

In this study, the presence of thousands of cells was observed at the highest rate among chromosomal abnormalities caused by nanoparticles. In addition, C-mitosis, multinucleus, anaphase bridge, adhesion, fracture, irregular chromosome and irregular dispersion were also observed. In the cells that will complete the phase of the interphase and enter the mitosis, there is a control point which is sensitive to the inability of the chromosomes to adhere to the mitotic yarns properly. If this checkpoint does not function properly, some abnormalities may occur [64]. Furthermore, clastogenic fractures may occur in chromosomes depending on the dose and duration of the exposed chemical.

If we take a look at some of the items we use in the study; in a study conducted with nanotitanium dioxide, it was stated that the substance did not produce chromosomal abnormalities in A.cepa [20]. In studies with zinc oxide nanoparticles, it has been stated that different doses of the substance cause chromosomal abnormalities in $A$. cepa and these abnormalities generally occur in the form of adhesion, bridge, binucleus etc [65].

Demir et al., [25] reported that, zinc and titanium oxide nanoparticles were applied to A.cepa root tip cells and examined the genotoxic effects of substances by comet test. At the end of the study, they concluded that both substances had genotoxic effects. In another study with titanium oxide, it was stated that the substance caused the formation of reactive oxygen species, which may cause abnormalities in chromosomes [66]. In 2016, Ghosh investigated the genotoxic effects of zinc oxide nanoparticles in A.cepa, V. faba and Nicotiana tabacum and determined increases in chromosomal abnormalities [67].

In this study, the reason of formation of chromosomal abnormalities determined as a result of our experimental observations can be grouped under 3 groups [68]. In the first group, mitotic chromosome abnormalities caused by chemicals, such as spindle strands, can be incorporated into C-mitosis, multipolarity and calcined chromosomes. In the other group, chromosomal adhesions that occur as a result of a physiological effect on chromosomes during cleavage can be considered [69]. Finally, defects in chromosomes; chromosome bridges, fragments and micronuclei, as well as chromosome breaks $[68,70]$.

The abnormality we called C-mitosis was first observed by Levan [71] in A. cepa root tips. C-mitosis is defined as the irregular dispersed cell cycle of chromosomes in metaphase. The effect of the chemical substance is similar to colchicine, but also disrupts the structure of the spindle threads. This situation is an indicator of the turbogenic effect [72]. As a result of this, the centromere division is delayed, the chromosomes are replicated, but not separated from each other. This anomaly in the metaphase also causes a decrease in the mitotic index. The presence of C-mitotic cells was also detected in test materials treated with a variety of different chemicals [73-78].

Anaphase bridge is another anomaly that occurs as a result of microscopic examinations. Chromosome bridges can usually occur as a result of the chemical effect of the substance used, breaking and recombination of chromosomes or as a result of the adhesion of chromosomes in metaphase [68, 79]. Similarly, inversion of chromosome segments or the formation of irregular translocations may cause chromosome bridges [77]. Chromosome bridges resulting from toxic and clastogenic effects are not recycled [80]. Chromosome bridges are formed by chromatin fibers formed by a combination of sister chromatids in metaphase. If the connections between them are stretched too much, the chromatids may break at or near the point of attachment in the anaphase. Fractures may occur at different points in both sister chromatids. The result is the formation of fragments that are similar to chromosome structures. This type of abnormality has been found in most studies with different chemicals $[70,73,77,78,81]$.

Multinucleated and binucleated cells were found at the root end of $A$. cepa treated with titanium dioxide, silicon dioxide, aluminum oxide, copper oxide and zinc oxide nanoparticles. These cells can be shown as the cause of the formation of nanoparticles inhibit cytokine. In many of the cells treated with these substances, cytokinesis was not observed following the telophase stage. While the cytoplasm division takes place, the two brothers remain co-surrounded by the 
same cell wall. Inhibition of cytokine and formation of binuclear cells were determined by Borah and Talukdar [75], Gömürgen [77], Sudhakar et al., [82], Kaushi [83], Çelik et al., [84], Türkoğlu [85].

Another abnormality found during the study is stickiness. Chromosome adhesions indicate that the chromosomes are formed as a result of the depolimerization effects of these chemicals on nucleic acids. Patil and Bhat [86] described the chromosome adhesiveness as physiological adhesion involving the chromatin material into the protein matrix. Adhesiveness can be defined as the effect of chemical substances on phosphate groups in DNA [87]. Liu et al. [80] stated that chromosome adhesiveness leads to irreversible cell death. Chromosome adhesions in metaphase also prevent the passage of chromosomes to the anaphase stage. The same type of chromosomal abnormality was highly observed in the test materials treated with food additives and pesticides [70, 74, 76-78, 88, 89].

Laggard chromosome is another abnormality observed in cells of test material treated with a small percentage of titanium oxide, silicon oxide, aluminum oxide, copper oxide and zinc oxide nanoparticles. It is due to the late chromosomes moving to different poles of the cell. Patil and Bhat [86] have stated that thick chromosomes may have a functional defect that may occur during the organization of spindle threads.

Other abnormalities observed in our study are chromosome fractures and irregular distribution of chromosomes. Chemicals causing breakage are defined as clastogenic agents and have been reported to their effects on chromosomes on DNA [90]. Rieger et al., [91] reported that some regions of the chromosomes react with chemicals and breaks occur in these regions in Vicia faba. In chromosomes, it is stated that the regions that are broken first are in the heterockromatic structure. At the same time, a defect on the spindle yarn causes irregular distribution of chromosomes. This type of abnormalities have been found in research with different chemicals $[68,75,77,78,88,92]$.

One of the most important reasons for the use of C. elegans in many scientific studies is that it is economic. In laboratory conditions, $E$. coli is nourished and grown on the prepared medium. Knowing the genetics of each cell from zygote to noodles,

the fact that their genes are $80 \%$ identical to human genes also allows us to use C. elegans as the appropriate model organism in the studies, the advantage of observing and analyzing the effect of a chemical on the entire organism [93]. The examination of $C$. elegans at biochemical and genetic levels provides progress in nanotoxicology. This model organism plays a role in determining the toxic dose, composition and biocompatibility of the nanoparticle. The anatomy of $C$. elegans helps to understand the interaction of biological surfaces (e.g. epithelium or intestinal cells) with nanoparticles that are similar to those of mammals. Gives explanatory information about the ways in which substances are taken into cells and their transmission to tissues and organs [94].

So far, the interaction between C. elegans and nanoparticles is often limited to assessments of the biology of the worm. No more samples were found to investigate the effects of these substances on the length of life, egg yield and physical growth [10, 95-99].

All of the nanoparticles we used reduced overall life span compared to control, decreased egg yield and caused a decrease in physical growth. The main cause of this situation is the formation of reactive oxygen nanoparticles used, and these reactive oxygen species can be concluded to affect life time, egg yield and physical growth adversely affect.

\section{Conclusion}

As a result of all these researches and findings, all nanoparticles we use have negative effects on both test systems. The results obtained are the result of a study conducted with limited test systems involving only a small proportion of the nanoparticles we encounter. Molecular and biochemical studies on different test systems need to be added to these data.

\section{Compliance with ethical standards}

\section{Acknowledgments}

The authors would like to thank Dr. Necati Özpınar for their help during the study.

\section{Disclosure of conflict of interest}

The authors declares no conflict of interest. 


\section{References}

[1] Al-Subiai SN, Arlt VM, Frickers PE, Readman JW, Stolpe B, Lead JR, Moody AJ and Jha AN. (2012). Merging nanogenotoxicology with eco-genotoxicology: an integrated approach to determine interactive genotoxic and sub-lethal toxic effects of C60 fullerenes and fluoranthene in marine mussels, Mytilus sp. Mutat. Res. 745(1-2), 92-103.

[2] Pfuhler S, Elespuru R, Aardema MJ, Doak SH, Maria Donner E, Honma M, Kirsch-Volders M, Landsiedel R, Manjanatha M, Singer T and Kim JH. (2013). Genotoxicity of nanomaterials: refining strategies and tests for hazard identification. Environ. Mol. Mutagen. 54 (4), 229-39.

[3] Azqueta A and Dusinska M. (2015). The use of the commet assay for the evaluation on the genotoxicity of nanomaterials. Front. Genet. 6.

[4] Asare N, Instanes C, Sandberg WJ, Refsnes M, Schwarze P, Kruszewski M and Brunborg G. (2012). Cytotoxic and genotoxic effects of silver nanoparticles in testicular cells. Toxicology. 291(1), 65-72.

[5] Ellegaard-Jensen L, Jensen KA and Johansen A. (2012). Nano-silver induces doseresponse effects on the nematode Caenorhabditis elegans. Ecotoxicology and Environmental Safety. 80, 216-223.

[6] Aslani F, Bagheri S, Muhd Julkapli N, Juraimi AS, Hashemi FS and Baghdadi A. (2014). Effects of Engineered Nanomaterials on Plants Growth: An Overview. The Scientific World Journal. 28.

[7] Srivastava V, Deepak G and Sharma YC. (2015). Critical Review on the Toxicity of Some Widely Used Engineered Nanoparticles. Ind. Eng. Chem. Res. 54, 6209-6233.

[8] Gajewicz A, Rasulev B, Dinadayalane TC, Urbaszek P, Puzyn T, Leszczynska D and Leszczynski J. (2012). Advancing risk assessment of engineered nanomaterials: application of computational approaches. Advanced Drug Delivery Reviews. 64(15), 1663-1693.

[9] Xia T, Kovochich M, Brant J, Hotze M, Semptf J, Oberley T, Sioutas C, Yeh JI, Wiesner MR and Nel AE. (2006). Comparison of the Abilities of Ambient and Manufactured Nanoparticles to Induce Cellular Toxicity According to an Oxidative Stress Paradigm. Nano Lett. 6, 1794-1807.

[10] Wang H, Wick RL and Xing B. (2009). Toxicity of nanoparticulate and bulk ZnO, Al2O3 and TiO2 to the nematode Caenorhabditis elegans. Environmental Pollution. 157(4), 1171-1177.

[11] Chen M and Mikecz A. (2005). Formation of nucleoplasmic protein aggregates impairs nuclear function in response to SiO2 nanoparticles. Experimental Cell Research. 305(1), 51-62.

[12] Shvedova AA, Kapralov O, Feng W, Kisin ER, Murray A, Mercer R, St Croix C, Lang M, Watkins S, Konduru N, Allen B, Conroy J, Mohamed BM, Meade AD, Volkov Y, Star A, Fadeel B and Kagan VE. (2012). Impaired clearance and enhanced pulmonary inflammatory/fibrotic response to carbon nanotubes in myeloperoxidase-deficient mice. PLoS ONE. 7(3), e30923.

[13] Peters A, Veronesi B, Calderón-Garciduenas L, Gehr P, Chen LC, Geiser M, Reed W, Rothen-Rutishauser B, Schürch $S$ and Schulz H. (2006). Translocation and potential neurological effects of fine and ultrafine particles a critical update. Particle and Fibre Toxicology. 3(13), 1-13.

[14] Geiser M, Rothen-Rutishauser B, Kapp N, Schürch S, Kreyling W, Schulz H, Semmler M, Hof VI., Heyder J and Gehr P. (2005). Ultrafine particles cross cellular membranes by nonphagocytic mechanisms in lungs and in cultured cells. Environmental Health Perspectives. 1555-1560.

[15] Khan M, Naqvi AH and Ahmad A. (2015). Comprative study of the cytotoxic and genotoxic potentials of zinc oxide and titanium dioxide nanoparticles. Toxicology Reports. 2, 765-774.

[16] Menard A, Drobne D and Jemec A. (2011). Ecotoxicity of nanosized TiO2. Review of in vivo data. Environ. Pollut. $159,677-684$.

[17] Zuverza-Mena N, Martinez-Fernandez D, Du W, Hernandez- Viezcas JA, Bonilla-Bird N, Lopez-Moreno LM, Komarek M, Peralta-Videa JR and Gardea-Torresdey JL. (2016).Exposure of engineered nanomaterials to plants: Insights into the physiological and biochemical responses-A review. Plant Physiology and Biochemistry.

[18] Foltête AS, Masfaraud JF, Bigorgne E, Nahmani J, Chaurand P, Botta C, Labille J, Rose J, Ferard JF and Cotelle S. (2011). Environmental impact of sunscreen nanomaterials: Ecotoxicity and genotoxicity of altered TiO2 nanocomposites on Vicia faba. Environ. Pollut. 159, 2515-2522. 
[19] Lei Z, Mingyu S, Xiao W, Chao L, Chunxiang Q, Liang C, Hao H, Xiaaqing L and Fashui H. (2008). Antioxidant stress in promoted by nano -anatase in spinach chloroplasts under UV-B radiation. Biol. Trace. Elem. Res. 121, 69-79.

[20] Klančnik K, Drobne D, Valant J and Dolenc Koce J. (2011). Use of a modified Allium test with nanoTiO2. Ecotox. Environ. Safe. 74, 85-92.

[21] Castiglione MR, Giorgetti L, Bellani L, Mucifora S, Bottega S and Spano C. (2016). Root responses to different types of TiO2 nanoparticles and bulk counterpart in plant model system Vicia faba L. Enviromental and Experimental Botany. 130, 11-21.

[22] Lee CW, Mahendra S, Zodrow K, Li D, Braam YC and Alvarez PJJ. (2010). Developmental phytotoxicity of metal oxide nanoparticles to Arabidopsis thaliana. Environ. Toxicol. Chem.. 29, 669-675.

[23] Lin BS, Diao S., Li CH, Fang LJ, Qiao SC and Yu M. (2004). Effects of TMS (nanostructured silicon dioxide) on growth of Changbai larch seedlings. J. Forest Res. 15, 138-140.

[24] Slomberg DL and Schoenfısch MH. (2012). Slica nanoparticle phytotoxicity to Arabidopsis thaliana. Environ. Sci. Technol. 46(18), 10247-10254.

[25] Demir E, Kaya N and Kaya B. (2014). Genotoxic effects of zinc oxide and titanium dioxide nanoparticles on root meristem cells of Allium cepa by comet assay. Turkish Journal of Biology. 38, 31-39.

[26] Koce JD, Drobne D, Klancnik K, Makovec D, Novak S and Hocevar M. (2014). Oxidative potential of ultraviolet-A irradiated or nonirradiated suspensions of titanium dioxide or silicon dioxide nanoparticles on Allium cepa roots. Environmental Toxicology and Chemistry. 33 (4), 858-867.

[27] Magdolenova Z, Collins A, Kumar A, Dhawan A, Stone V and Dusinska M. (2014). Mechanisms of genotoxicity. A review of in vitro and in vivo studies with engineered nanoparticles. Nanotoxicology. 8(3), 233-278.

[28] Guichard Y, Fontana C, Chavinier E, Terzetti F, Gaté L, Binet S and Darne C. (2016).Cytotoxic and genotoxic evaluation of different synthetic amorphous silica nanomaterials in the V79 cell line. Toxicology and Industrial Health. 32(9), 1639-1650.

[29] Kwon JY, Lee SY, Koedrith P, Lee JY, Kyoung-Min K, Jae-Min O, Yang SI, Meyoung-Kon K, Lee JK, Jeong J, Maeng EH, Lee BJ and Seo YR. (2014). Lack of genotoxic potential of ZnO nanoparticles in in vitro and in vivo tests. Mutation Research. 761, 1-9.

[30] Hackenberg S, Scherzed A, Technau A, Kessler M, Froelich K, Ginzkey C, Koehler C, Burghartz M, Hagen R and Kleinsasser N. (2011). Cytotoxic, genotoxic, and proinflammatory effects of zinc oxide nanoparticles in human nasal mucosa cells in vitro. Toxicol. In Vitro. 25, 657-663.

[31] Moos PJ, Chung K, Woessner D, Honeggar M, Shane Cutler N and Veranth JM. (2010). ZnO particulate matter requires cell contact for toxicity in human colon cancer cells. Chem. Res. Toxiocol. 23, 733-739.

[32] Manzo S, Rocco A, Carotenuto R, De Luca Picione F, Lucia Miglietta M, Rametta G and Di Francia G. (2011). Investigation of $\mathrm{ZnO}$ nanoparticles' ecotoxicological effects towards different soil organisms. Environ. Sci. Pollut. Res. 18, 756-763.

[33] Gabbay J, Borkow G, Mishal JE, Magen Zatcoff R and Shemer-Avni Y. (2006). Copper oxide impregnated textiles with potent biocidal activities. J. of Industrial Textiles. 35(4), 323-335.

[34] Prakash MGN, Seung-Hyun K and Ill Min Chung. (2014). Copper oxide nanoparticle toxicity in mung bean (Vigna radiata L.) seedlings: physiological and molecular level responses of in vitro grown plants. Acta Physiol. Plant. 36, 2947-2958.

[35] Shi JY, Abid AD, Kennedy IM, Hristova KR and Silk WK. (2011). To duckweeds (Landoltia punctata), nanoparticulate copper oxide is more inhibitory than the soluble copperin the bulk solution. Environmental Pollution. 159(5), 1277-1282.

[36] Özkaleli M and Erdem A. (2017). Ecotoxic Effects of Copper Oxide Nanoparticles on Chlorella vulgaris. Sinop Uni. J. Nat. Sci. 2 (1), 13-23.

[37] Aruoja V, Dubourguier HC, Kasemets K and Kahru A. (2009). Toxicity of nanoparticles of CuO, ZnO and TiO2 to microalgae Pseudokirchneriella supcapiata. Sci. Total Environ. 407, 1461-1468.

[38] Perreault F, Samadani M and Dewez D. (2014). Effects of soluble copper released from copper oxide nanoparticles solubilisation on growth and photosynthetic processes of Lemna gibba L. Nanotoxicology. 8, 374-382. 
[39] Kearn M. (2004). Development and applications of ultrafine Aluminium powders. Materials Science and Engineering A. 375-377, 120-126.

[40] IARC. (2010). Some non-heterocyclic polycyclic aromatic hydrocarbons and some related exposures. IARC Monogr. Eval. Carcinog. Risks Hum. 92, 1-853.

[41] Balasubramanyam A, Sailaja N, Mahboob M, Rahman MF, Hussain SM and Grover P. (2009). In vivo genotoxicity assessment of aluminium oxide nanomaterials in rat peripheral blood cells using the comet assay and micronucleus test. Mutagenesis. 24, 245-251.

[42] Wagner AJ, Bleckmann CA, Murdock RC, Schrand AM, Schlager JJ and Hussain SM. (2007). Cellular interaction of diffirent forms of aluminum nanoparticles in rat alveolar macrophages. J. Phys. Chem. Biol. 111, 7353-7359.

[43] Murdock RC, Braydich-Stolle L, Schrand AM, Schager JJ and Hussain SM. (2008). Characterization of nanomaterial dispersion in solution prior to in vitro exposure using dynamic light scattering technique. Toxicol. Sci. 101, 239-253.

[44] Fiskesjo G. (1985). The Allium test as a standart in enviromental monitoring. Hereditos 102, 99-112.

[45] Riddle DL, Blumenthal T, Meyer BJ and Pries JR. (1997). C. elegans II. Cold Spring Harbor Laboratory Press. Section I, The Biological Model.

[46] Klug WS, Cummings MR and Spencer CA. (2011). Genetik Kavramlar. Palme Yayıncılık. 764.

[47] Hulme SE and Whitesides GM. (2011). Angew. Chem.-Int.Edit. 50, 4774-807.

[48] Duan SM, Wu Q, Li Y, Tang M and Wang D. (2012). Evaluation of Environmental Safety Concentrations of DMSA Coated $\mathrm{Fe}_{2} \mathrm{O}_{3}-\mathrm{NPs}$ Using Different Assay Systems in Nematode Caenorhabditis elegans. Plos One. 7, e43729.

[49] Ma H, Bertsch PM, Gleen TC, Kabengi NJ and Williams PL. (2009). Toxicity of manufactured zinc oxide nanoparticles in the nematode Caenorhabditis elegans. Environ. Toxicol. Chem. 28, 1324-30.

[50] Pirinç B and Türkoğlu Ş. (2016). Investigation of The Effects of Ethyl Paraben and Methyl Paraben on The Longevity and Fecundity of Caenorhabditis elegans. Cumhuriyet University Faculty of Science Journal (CSJ). 37, 4, 31-50.

[51] Singh N, Manshian B, Gareth JS, Jenkins GJS, Griffiths SM, Williams PM, Maffeis TGG, Wright CJ and Doak SH. (2009). Nanogenotoxicology: the DNA damaging potential of engineered nanomaterials. Biomaterials. 30 (2324), 3891-3914.

[52] Revell PA. (2006). The biological effects of nanoparticles. Nanotechnol. Percept. 2, 283-98.

[53] Atlı-Şekeroğlu Z. (2013). From nanotechnology to nanogenotoxicology: genotoxic effect of cobalt-chromium nanoparticles. Turkish Bulletin of Hygiene and Experimental Biology. 70(1), 33-42.

[54] Oberdörster G, Kane AB, Klaper D and Hurt RH. (2013). Nanotoxicolog. C.D. Klassen (Ed), Casarettand Doull's Toxicology the Basic Science of Pisons.New york. Mc Graw Hill. 1189-1229.

[55] Goujon E, Sta C, Trivella A, Goupil P, Richard C and Ledoigt G. (2014). Genotoxicity of sulcotrione pesticide and photoproducts on Allium cepa root meristem. Pesticide Biochemistry and Physiology. 113, 47-54.

[56] Webster PL and Davidson D. (1969). Changes in the duration of the mitotic cycle induced by colchicine and indol3yl-acetic acid in Vicia faba roots. Journal of Experimental Botany. 20(3), 671-685.

[57] Çalbay Ö. (2014). Genotoxic effects of copper oxide and silicon dioxide nanoparticles in Allium cepa. Gazi University, Graduate Scholl of Natural and Applied Sciences, (M. Sc. Thesis). 118s, Ankara.

[58] Vermeulen K, Van Bockstaele DR and Berneman ZN. (2003). The cell cycle: a review of regulation, deregulation and therapeutic targets in cancer. Cell Proliferation. 36(3), 131-149.

[59] Fernandes TCC, Mazzeo DEC and Marin-Morales MA. (2007). Mechanism of micronuclei formation in polyploidizated cells of Allium cepa exposed to trifluralin herbicide. Pestic. Biochem. Phys. 88, 252-259.

[60] Karaismailoglu MC. (2014). Investigation of the Cytotoxic and genotoxic effects of Artemisia annua Methanol extract with the Allium test. Ekoloji. 23(91), 64-74.

[61] Konotop YO, Kovalenko MS, Ulynets VZ, Meleshko AO, Batsmanova LM and Taran NY. (2014). Phytotoxicity of colloidal solutions of metal containing nanoparticles. Cytology and Genetics. 48(2), 99-102. 
[62] Paul A, Nag S and Sinha K. (2013). Cytological effects of blitox on root mitosis of Allium cepa. International Journals of Scientific Research Publications. 3(5), 1-7.

[63] Türkoğlu Ş. (2012). Determination of genotoxic effects of chlorfenvinphos and fenbuconazole in Allium cepa root cells by mitotic activity chromosome aberration DNA content and comet assay. Pestic. Biochem. Phys. 103, 224230 .

[64] Li F, Ambrosini G, Chu EY, Plescia J, Tognin S, Marchisio PC and Altieri DC. (1998). Control of apoptosis and mitotic spindle checkpoint by survivin. Nature. 396(6711), 580-584.

[65] Kumari M, Khan SS, Pakrashi S, Mukherjee A and Chandrasekaran N. (2011). Cytogenetic and genotoxic effects of zinc oxide nanoparticles on root cells of Allium cepa. Journal of Hazardous Materials. 190, 613-621.

[66] Pakrashi S, Jain N, Dalai S, Jayakumar J, Chandrasekaran PT, Raichur AM, Chandrasekaran N and Mukherjee A. (2014). In vivo genotoxicity assessmentof titanium dioxide nanoparticles by Allium cepa root tip assay at high exposure concentrations. Plos one. 9 (2), e87789.

[67] Ghosh M, Jana A, Sinha S, Jothiramajayam M, Nag A, Chakraborty A and Mukherjee A. (2016). Effects of ZnO nanoparticles in plants: Cytotoxicity, genotoxicity, deregulation of antioxidant defenses and cell-cycle arrest. Mutation Research Toxicology and Environmental Mutagenesis. 87, 25-32.

[68] Badr A. (1986). Effects of the s-triazine herbicide terbutryn on mitosis chromosomes andnucleic acids in root tips of Vicia faba root meristems. Cytologia. 51, 571-578.

[69] Savage JRK. (1975). Classification and relationships of induced chromosomal structural changes. Journal of Medical Genetics. 12, 103-122.

[70] El-Ghamery AA, El Nahas AI and Mansour MM. (2000). The action of atrazine herbicide as an inhibitor of cell divisions on chromosomes and nucleic acids content in root meristems of Allium cepa and Vicia faba. Cytologia. 65, 277-287.

[71] Levan A. (1938). The effect of colchicine on root mitoses in Allium. Hereditas. 24, 471.

[72] Shahin SA and El-Amoodi KHH. (1991). Induction of numerical chromosomal aberrations during DNA synthesis using the fungicides nimrod and rubigan -4 in root tips of Vicia faba L. Mutat. Res. 261,169-176.

[73] El-Ghamery AA, El-Kholy MA and Abou El-Yousser MA. (2003). Evaluation of cytological effects of Zn+2 in relation to germination and root growth of Nigella sativa L. and Triticum aestivum L. Mutation Research. 537, 29-41.

[74] Rencüzoğulları E, İla HB, Karayıldız A and Topaktaş M. (2001). Chromosome aberrations and sister chromatid exchanges in cultured human lymphocytes treated with sodium metabisulfit a food preservative. Mutation Research/Genetics Toxicology Environmental Mutagenesis. 490, 107- 112.

[75] Borah SP and Talukdar J. (2002). Studies on the cytotoxic effects of extract of castor seed (Ricinus communis L.). Cytologia. 67, 235-243.

[76] Dönbak L, Rencüzoğulları E and Topaktaş M. (2002). The cytogenetic effects of the food additive boric acid in Allium cepa L. Cytologia. 67, 153-157.

[77] Gömürgen AN. (2005). Cytological effect of the potassium metabisulphite and potssium nitrate food preservative on root tips of Allium cepa L. Cytologia. 70, 119-128.

[78] Türkoğlu Ş. (2007). Genotoxicity of five food preservation tested on root tips of Allium cepa L. Mutation Research. 626, 4-14.

[79] Tomkins DJ and Grant WF. (1972). Comparative cytological effects of pesticides menazon, metrobromuron and tetrachloro nitrile in Hordeum and Tradescanita. Canadian Journal of Genetics and Cytology. 14, 245-256.

[80] Liu DH, Jiang WS and Wang CL. (1996). Effect of Zn+2 on root growth, cell divisions and nucleoli of Allium cepa L. Environmental Science. 8, 21-27.

[81] İnceer H, Eryiğit H and Beyazoğlu O. (2004). Effects of the herbicide linuron on somatic chromosomes of Helianthus annus L. (Sunflower). Caryologia. 57(2), 127-132.

[82] Sudhakar R, Gowda N and Venu G. (2001). Mitotic abnormalites induced by silk dyeing industry effluents in the cells of Allium cepa. Cytologia. 66, 235-239.

[83] Kaushi GC. (1996). Cytological effects of Lantana camara L. leaf extract on Vicia faba root tip cells. Advances in Plant Sciences. 9, 159-164. 
[84] Çelik M, Yüzbaşığlu D, Ünal F, Arslan O and Kasap R. (2005). Effects of dinocap on the mitosis of Allium cepa L. Cytologia. 70(1), 13-22.

[85] Türkoğlu Ş. (2008). Evaluation of genotoxic effects of sodium sulphite, potassium sulphiteand calcium sulphite on the root meristem cells of Allium cepa. Food and Chemical Toxicology. 46, 2035-2041.

[86] Patil BC and Bhat TGI. (1992). A comparative study of MH and EMS in the induction of chromosomal aberrations on lateral root meristem in Clitoria termata L. Cytologia. 57, 259-264.

[87] Valle BL and Ulmer DD. (1972). Biochemical effects of mercury, cadmium and lead. Annual Review of Biochemistry. 41, 92-128.

[88] Badr A and İbrahim AG. (1987). Effects of herbicide glean on mitosis, chromosomes and nucleic acids in Allium cepa and Vicia faba root meristems Cytologia. 52, 293-302.

[89] Yüzbașioğlu D. (2003). Cytogenetic effects of fungicide Afugan on the meristematic cells of Allium cepa L. Cytologia. 68(3), 237-243.

[90] Grant WF. (1978). Chromosome aberrations in plants as amonitoring system. Environ. Health Perspect. 27, 3743.

[91] Reiger R, Michaelis A and Green MM. (1976). A Glossary of genetics and cytogenetics. Springer-Verlag, Berlin.

[92] Shanker R, Chauakan LKS and Prahlad KS. (1987). Cytological effects of the herbicide Garlon-4 on root mitosis of Allium cepa. Cytologia. 54, 465-472.

[93] Hertweck M, Hoppe T and Baumeister R. (2003). C. elegans, a model for agind with high-troughput capacity. Exp. Gerontol. 38 (3), 345-346.

[94] Gonzalez-Moragas L, Roig A and Laromaine A. (2015). C. elegans as a tool for in vivo nanoparticle assessment. Adv. Colloid. Interface Sci. 219, 10-26.

[95] Kim J, Shirasawa T and Miyamoto Y. (2010). The effect of TAT conjugated platinum nanoparticles on lifespan in a nematode Caenorhabditis elegans model. Biomaterials. 31, 5849-54.

[96] Mohan N, Chen NS, Hsieh HH, Wu YC and Chang HC. (2010). In Vivo Imaging and Toxicity Assessments of Fluorescent Nanodiamonds in Caenorhabditis elegans. Nano Lett. 10, 3692-9.

[97] Qu Y, Li W, Zhou Y, Liu X, Zhang L, et al. (2011) Full assessment of fate and physiological behavior of quantum dots utilizing Caenorhabditis elegans as a model organism. Nano Lett. 11, 3174-3184.

[98] Kim SW, Nam SH and An YJ. (2012). Interaction of silver nanoparticles with biological surfaces of Caenorhabditis elegans. Ecotoxicol. Environ. Saf. 77, 64-70.

[99] Pluskota A, Horzowski E, Bossinger 0 and von Mikecz A. (2009). In Caenorhabditis elegans Nanoparticle-BioInteractions Become Transparent: Silica-Nanoparticles Induce Reproductive Senescence. PLOS ONE. 4(8), e6622.

\section{How to cite this article}

Atacı G and Türkoğlu Ş. (2020). The Investigation of Toxic, Genotoxic and Cytotoxic Effects of Various Nanoparticles in Allium cepa and Caenorhabditis elegans Test Systems. World Journal of Advanced Research and Reviews, 5(1), 16-35. 